\title{
Detection and identification of pathogenic trypanosome species in tsetse flies along the Comoé River in Côte d'Ivoire
}

\author{
Vincent Djohan ${ }^{1,2, *}$, Dramane Kaba ${ }^{1}$, Jean-Baptiste Rayaissé ${ }^{3}$, Guiguigbaza-Kossigan Dayo ${ }^{3}$, \\ Bamoro Coulibaly ${ }^{1}$, Ernest Salou ${ }^{3}$, Fabien Dofini ${ }^{3}$, Alain De Marie Koffi Kouadio ${ }^{1}$, \\ Hervé Menan ${ }^{2}$, and Philippe Solano ${ }^{4}$ \\ 1 Institut Pierre Richet/INSP, 01 BP 1500 Bouaké, Côte d'Ivoire \\ 2 Université Félix Houphouët Boigny, BPV 34 Abidjan, Côte d'Ivoire \\ 3 CIRDES, BP 454 Bobo-Dioulasso, Burkina Faso \\ 4 IRD UMR 177 INTERTRYP-IRD-CIRAD, 34398 Montpellier, France
}

Received 8 January 2015, Accepted 15 May 2015, Published online 2 June 2015

\begin{abstract}
In order to identify pathogenic trypanosomes responsible for African trypanosomiasis, and to better understand tsetse-trypanosome relationships, surveys were undertaken in three sites located in different eco-climatic areas in Côte d'Ivoire during the dry and rainy seasons. Tsetse flies were caught during five consecutive days using biconical traps, dissected and microscopically examined looking for trypanosome infection. Samples from infected flies were tested by PCR using specific primers for Trypanosoma brucei s.1., T. congolense savannah type, T. congolense forest type and T. vivax. Of 1941 tsetse flies caught including four species, i.e. Glossina palpalis palpalis, G. p. gambiensis, G. tachinoides and G. medicorum, 513 (26\%) were dissected and $60(12 \%)$ were found positive by microscopy. Up to $41 \%$ of the infections were due to T. congolense savannah type, $30 \%$ to $T$. vivax, $20 \%$ to $T$. congolense forest type and $9 \%$ due to T. brucei s.l. All four trypanosome species and subgroups were identified from G. tachinoides and G. p. palpalis, while only two were isolated from G. p. gambiensis (T. brucei s.1., T. congolense savannah type) and G. medicorum (T. congolense forest, savannah types). Mixed infections were found in $25 \%$ of cases and all involved T. congolense savannah type with another trypanosome species. The simultaneous occurrence of $T$. brucei s.l., and tsetse from the palpalis group may suggest that human trypanosomiasis can still be a constraint in these localities, while high rates of $T$. congolense and $T$. vivax in the area suggest a potential risk of animal trypanosomiasis in livestock along the Comoé River.
\end{abstract}

Key words: Trypanosomes, Trypanosomiasis, Riverine tsetse flies, Côte d'Ivoire.

Résumé - Détection et identification des espèces de trypanosomes pathogènes chez les glossines le long du fleuve Comoé en Côte d'Ivoire. Dans le but d'identifier les trypanosomes responsables de trypanosomoses africaines humaine et animale et de mieux connaître leurs relations avec les tsé-tsé, des enquêtes ont été réalisées dans trois sites situés dans différentes zones éco-climatiques de Côte d'Ivoire et ce, durant les saisons sèche et pluvieuse. Les glossines ont été capturées durant 5 jours consécutifs en utilisant des pièges biconiques, disséquées et examinées au microscope à la recherche d'infection trypanosomienne. Des échantillons de glossines infectées ont été analysées par PCR en utilisant des amorces spécifiques à Trypanosoma brucei s.1., T. congolense type savane, T. congolense type forêt et T. vivax. Sur les 1941 tsé-tsé capturées et comprenant 4 espèces, Glossina palpalis palpalis, G. p. gambiensis, G. tachinoides et G. medicorum, 513 (26\%) ont été disséquées et 60 (12\%) ont été trouvées positives par microscopie. Une proportion allant jusqu'à $41 \%$ des infections était due à T. congolense type savane, $30 \%$ à $T$. vivax, $20 \%$ à $T$. congolense type forêt et $9 \%$ à $T$. brucei s. 1 . Les quatre espèces et sous-groupes de trypanosomes ont été isolés chez G. tachinoides et $G$. p. palpalis tandis que seulement deux ont été isolés chez $G$. p. gambiensis (T. brucei s.1., T. congolense type savane) et G. medicorum (T. congolense types forêt et savane). Les infections mixtes ont été retrouvées dans $25 \%$ des cas et toutes impliquaient $T$. congolense type savane et une autre espèce de trypanosome. La présence simultanée de $T$. brucei s.l. et de mouches tsétsé du groupe palpalis suggère que la trypanosomose humaine peut encore être une contrainte dans ces localités. Le taux élevé de $T$. congolense et de $T$. vivax dans cette zone suggère un risque potentiellement élevé de trypanosomose animale chez le bétail le long du fleuve Comoé.

\footnotetext{
*Corresponding author: vincentdjohanl@yahoo.fr
} 


\section{Introduction}

Human African Trypanosomiasis (HAT), or sleeping sickness, one of the most neglected tropical diseases in the world [23], occurs in the most remote areas of Sub-Saharan Africa, where health systems are often deficient or destabilised by wars. Trypanosomiasis caused by Trypanosoma brucei gambiense represents up to $98 \%$ of the declared cases [7] and is endemic in a geographically limited area of West and Central Africa [26]. The number of reported cases these two last years was fewer than 8000 , but this is certainly underestimated due to incomplete surveillance [31]. Animal African Trypanosomiasis (AAT) is also a major constraint to the development of the livestock sector in Sub-Saharan Africa. The disease induces a decrease of livestock productivity and reduces its density up to $70 \%$. Meat and milk sales are reduced by $50 \%$, calving by $20 \%$, while the calf mortality rate is increased by $20 \%$ $[15,29]$. Tsetse flies are the main vectors of trypanosomes, protozoan parasites of the genus Trypanosoma, pathogens of both HAT and AAT [11]. They are therefore a key factor in trypanosomiasis epidemiology by their central role in trypanosome transmission to vertebrate hosts. Identification of trypanosomes in tsetse flies could be a good indicator for HAT and AAT within an area. Nowadays, parasitological diagnosis is used in field conditions [30] but it is not very sensitive, partly due to the low parasitaemia observed in a natural host infection $[19,24]$, and polymerase chain reaction (PCR) which is very sensitive and specific, is widely used for trypanosome identification in the laboratory [3, 8]. Detection and identification of pathogenic trypanosomes in tsetse flies along the Comoé River will highlight the areas at risk of human and animal trypanosomiasis. This will help in the use of adapted control methods in this increasingly anthropised habitat, as this part of the country has fertile arable land for agriculture and is suitable for livestock. The main purpose of this study was to identify trypanosomes circulating in tsetse along the Comoé River, and to better understand the relationship between tsetse and trypanosomes in this area.

\section{Materials and methods}

\section{Study sites}

Three sites located in different eco-climatic areas were selected to identify pathogenic trypanosomes circulating along the Comoé River in Côte d'Ivoire (Fig. 1). Going from South to North along Comoé River, the first site is located in the South, in Aboisso Comoé, Alépé District $\left(05^{\circ} 46^{\prime} \mathrm{N}\right.$ and $03^{\circ} 10^{\prime} \mathrm{W}$ ) in the Yaya Forest Reserve [1]. The vegetation is very lush with dense forest degraded in some places. The second site, between the villages of Groumania and Sérébou $\left(8^{\circ} 23^{\prime} \mathrm{N}\right.$ and $\left.4^{\circ} 26^{\prime} \mathrm{W}\right)$, lies on the forest-savannah transition area in the middle of the country [1]. The vegetation consists of a mosaic of wet savannah and dry forest along a relatively thin riparian forest. The third site is located in the North, in the Comoé National Park along the border with Burkina Faso near Kafolo village $\left(9^{\circ} 35^{\prime} \mathrm{N}\right.$ and $\left.5^{\circ} 12^{\prime} \mathrm{W}\right)$ in Kong District, with vegetation consisting of gallery forest along the Comoé River and shrubby savannah hosting some wild game [1].

\section{Entomological surveys}

The surveys were conducted during the dry season (from January 26 to March 10, 2012) and during the rainy season (from October 22 to November 14, 2012) except in Aboisso Comoé where they were only carried out during the dry season. At each site, tsetse were caught using 25 biconical traps [5], set in five radial transects starting from the immediate bank of the river, going to the savannah. Surveys lasted five consecutive days for each season, with a daily collection of catching cages. For each trap, geographic coordinates were recorded using a GPS. Collected tsetse were counted per species and sex and then dissected to isolate on a slide, proboscis, midgut and salivary gland for trypanosome research, using a microscope. When at least one of these organs was found to be infected, all three organs of the tsetse fly were collected individually in Eppendorf ${ }^{\circledR}$ microtubes containing $50 \mu \mathrm{L}$ of sterile distilled water and kept on the field at about $8^{\circ} \mathrm{C}$ and then at the laboratory, at $-20^{\circ} \mathrm{C}$ until DNA extraction.

\section{Identification of trypanosomes}

After DNA extraction from the different organs of infected tsetse flies, standard PCR was performed using specific primers for Trypanosoma congolense savannah type, T. congolense forest type, T. vivax west Africa and T. brucei s.l. This diagnosis was made using specific satellite sequences of trypanosome taxonomic groups $[20,21]$. DNA samples were amplified in $25 \mu \mathrm{L}$ reaction blend containing: $10 \mathrm{mM}$ Tris- $\mathrm{HCl} \mathrm{pH} 8.3$, $50 \mathrm{mM} \mathrm{KCl}, 200 \mathrm{mM}$ each of four deoxynucleotide triphosphates (dNTPs), $1 \mu \mathrm{M}$ of each primer and 0.5 units of Taq DNA polymerase. This blend was placed in a thermocycler with the PCR conditions comprising an initial denaturation step at $94^{\circ} \mathrm{C}$ for $3 \mathrm{~min}$, then 40 cycles of $94^{\circ} \mathrm{C}$ for $30 \mathrm{~s}$, $55^{\circ} \mathrm{C}$ for $30 \mathrm{~s}$, and $72^{\circ} \mathrm{C}$ for $1 \mathrm{~min}$. The elongation step was continued at $72^{\circ} \mathrm{C}$ for $5 \mathrm{~min}$. Five $\mu \mathrm{L}$ of each amplified sample was resolved by electrophoresis in a $1.5 \%$ agarose gel, stained with ethidium bromide and photographed under ultraviolet light. A positive control (with the reference DNA) and a negative control (without DNA and with only distilled water) were added to each reaction series.

\section{Statistical analysis}

Data were analysed using the Statistical Package for the Social Sciences (SPSS) Version 16.0 software. The proportions were statistically analysed with the Chi square test and comparison of means was performed using Student's $t$-test.

\section{Results}

\section{Entomological surveys}

A total of 1941 tsetse flies were caught on the three sites with 1307 (67.4\%) during the dry season and $633(32.6 \%)$ during the rainy season. Caught tsetse fly species and subspecies proportional abundances were 67.1\% (1303) for 




Figure 1. Location of study sites along the Comoé River in Côte d'Ivoire.

G. tachinoides, $16.8 \%$ (327) for G. p. gambiensis, $15.5 \%$ (300) for G. p. palpalis, and 0.5\% (10) for G. medicorum. G. p. palpalis was caught only in the southern (Aboisso Comoé) and central (Groumania) parts of the country, while the others (but not G. p. palpalis) were caught in the north at the Comoé National Park (Kafolo). Tsetse fly apparent densities per trap (ADP) on the three different sites are presented in Table 1.
Sixty (60) flies from a total of 513 dissected were found positive for trypanosome infection using microscopes, yielding an overall infection rate of all species combined of $11.7 \%$. No salivary gland infection was observed. On the other hand, the proboscis and midgut were, respectively, infected at $4.1 \%$ and $6.8 \%$. Proboscis and midgut combined infections were observed in $0.8 \%$ of cases. The tsetse fly infection rate 
Table 1. Apparent Density per Trap (ADP) and tsetse infection rate depending on the species, areas and seasons.

\begin{tabular}{|c|c|c|c|c|c|c|c|c|}
\hline \multirow[t]{2}{*}{$\overline{\text { Site }}$} & \multirow[t]{2}{*}{ Species } & \multicolumn{3}{|c|}{ Dry season } & \multicolumn{3}{|c|}{ Rainy season } & \multirow[t]{2}{*}{ Stat. $(p)$} \\
\hline & & Abundance $(n, \%)$ & ADP & $\%$ Infection & Abundance $(n, \%)$ & ADP & $\%$ Infection & \\
\hline \multirow{3}{*}{ Kafolo } & G. tachinoides & $928(78.3 \%)$ & 7.424 & 16.84 & $375(82.4 \%)$ & 3 & 16.67 & 0.99 \\
\hline & G. p. gambiensis & $252(21.3 \%)$ & 2.016 & 7.89 & $75(16.5 \%)$ & 0.6 & 7.14 & 0.72 \\
\hline & G. medicorum & $5(0.4 \%)$ & 0.04 & 0 & $5(1.1 \%)$ & 0.04 & 40 & - \\
\hline Groumania & G. p. palpalis & $99(100 \%)$ & 0.7 & 1.12 & $178(99.4 \%)$ & 1.432 & 8.72 & 0.0081 \\
\hline Aboisso-Comoé & G. p. palpalis & $23(100 \%)$ & 0.184 & 10 & - & - & - & - \\
\hline \multirow{3}{*}{ Kafolo } & G. tachinoides & $928(78.3 \%)$ & 7.424 & 16.84 & $375(82.4 \%)$ & 3 & 16.67 & \\
\hline & G. p. gambiensis & $252(21.3 \%)$ & 2.016 & 7.89 & $75(16.5 \%)$ & 0.6 & 7.14 & \\
\hline & Stat. (p) & \multicolumn{2}{|c|}{0.00045} & \multicolumn{4}{|c|}{0.0253} & \\
\hline
\end{tabular}

ADP: Apparent Density per Trap.

did not significantly vary in Kafolo for G. tachinoides and G. p. gambiensis whatever the season $(p>0.05)$ (Table 1). In Groumania on the contrary, the infection rate of $G$. p. palpalis significantly increased from $1.12 \%$ to $8.72 \%(p=0.0081)$ in the rainy season (Table 1). Comparison between tsetse species in Kafolo showed significantly higher infection rates for G. tachinoides than G. p. gambiensis during the dry season $(p=0.00045)$ as during the rainy season $(p=0.0253)$ (Table 1).

\section{Identification of trypanosomes}

Organs of 58 tsetse flies out of the 60 found positive by microscope were analysed by PCR. A range of $75.9 \%$ $(44 / 58)$ of flies whose samples were analysed by PCR was identified, suggesting that $24.1 \%$ of trypanosomes circulating in this area would be some species other than those targeted in this study. From the 44 samples that were identified, 18 (40.9\%) were T. congolense savannah type, $13(29.5 \%)$ were $T$. vivax, $9(20.5 \%)$ were $T$. congolense forest type and 4 (9.1\%) were T. brucei s.l. (Fig. 2). T. congolense s.l. represents $61.4 \%$ of trypanosome species circulating along Comoé River. All types of trypanosomes were identified in G. tachinoides and G. p. palpalis, unlike G. p. gambiensis and G. medicorum in which only two were found, namely $T$. brucei s.l. and $T$. congolense savannah type for G. p. gambiensis and T. congolense forest type and $T$. congolense savannah type for G. medicorum (Table 2). Mixed infections accounted for $25 \%$ of all infections (Table 3). Among mixed infections, double infections $(22.7 \%)$ and triple infections $(2.3 \%)$ were noted. Mixed infections were mostly found in G. tachinoides.

\section{Discussion}

To improve our knowledge on the distribution of trypanosomes responsible for HAT and AAT in Côte d'Ivoire, tsetse flies were caught and dissected along the Comoé River. The identification of pathogenic trypanosomes in tsetse flies has helped to highlight potential risks for human and animal trypanosomiasis associated with these biotopes. G. palpalis and $G$. tachinoides were the two predominant species on these sites, justifying their primary role in trypanosome transmission

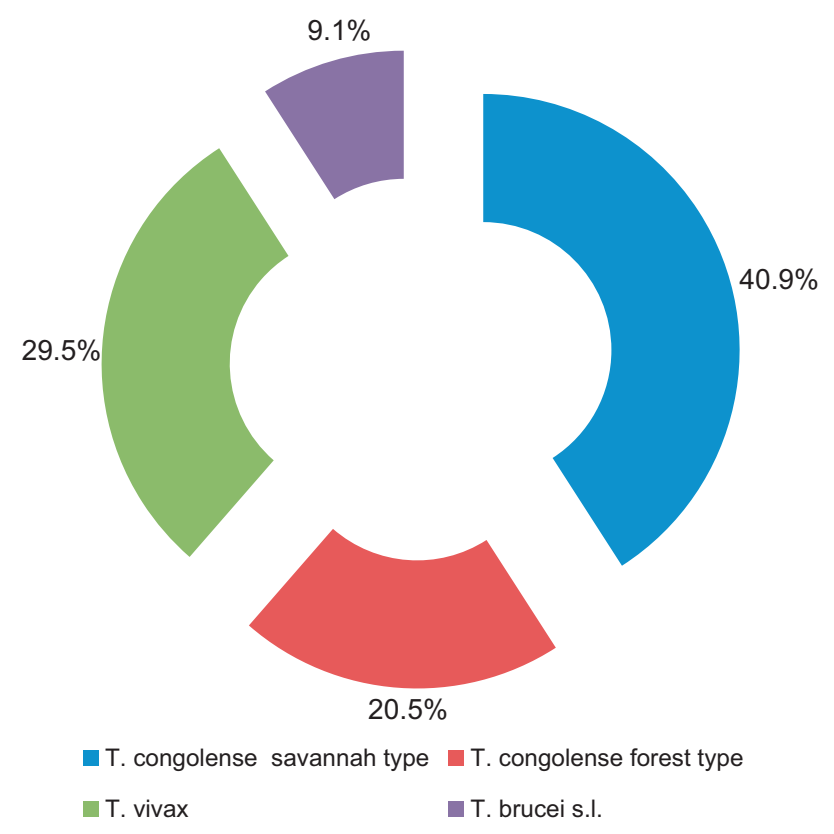

Figure 2. Proportions of trypanosome types circulating along Comoé River in Côte d'Ivoire.

in Côte d'Ivoire [16]. G. p. palpalis was caught in the south (Aboisso-Comoé) and in the centre (Groumania) while G. $p$. gambiensis was only caught in the north (Kafolo). In a previous study undertaken at the far south of the Comoé National Park at Gansé, along Comoé River, Kaba [13] caught, contrarily to our survey, more G. p. gambiensis than G. tachinoides. The relatively high ADPs in Kafolo may be explained by a steady presence of hosts in this area. This faunal stability would also be the reason why the infection rate does not vary significantly for the two main vectors of this site (G. tachinoides and G. p. gambiensis) whatever the season. On the same site, $G$. tachinoides was significantly more infested than G. $p$. gambiensis whatever the season $(p=0.00045$ in the dry season and $p=0.0253$ in the rainy season). In Groumania, the infection rate of G. p. palpalis increased significantly during the rainy season. A combination of factors including favourable climatic conditions for the survival and dispersal ability of this species and abundant vegetation attracting 
Table 2. Trypanosome species and subgroup frequency by tsetse species.

\begin{tabular}{lccccc}
\hline Tsetse species & $\mathrm{Tv}$ & $\mathrm{Tb}$ & $\mathrm{Tcf}$ & $\mathrm{Tcs}$ & Total \\
\hline G. tachinoides & $12 / 44(27.2 \%)$ & $1 / 44(2.3 \%)$ & $4 / 44(9.1 \%)$ & $10 / 44(22.7 \%)$ & $27 / 44(61.4 \%)$ \\
G. p. palpalis & $1 / 44(2.3 \%)$ & $2 / 44(4.5 \%)$ & $4 / 44(9.1 \%)$ & $5 / 44(11.4 \%)$ & $12 / 44(27.3 \%)$ \\
G. p. gambiensis & $0 / 44(0 \%)$ & $1 / 44(2.3 \%)$ & $0 / 44(0 \%)$ & $1 / 44(2.3 \%)$ & $2 / 44(4.5 \%)$ \\
G. medicorum & $0 / 44(0 \%)$ & $0 / 44(0 \%)$ & $1 / 44(2.3 \%)$ & $2 / 44(4.5 \%)$ & $3 / 44(6.8 \%)$ \\
Total & $13 / 44(29.5 \%)$ & $4 / 44(9.1 \%)$ & $9 / 44(20.5 \%)$ & $18 / 44(40.9 \%)$ & $44 / 44(100 \%)$ \\
\hline
\end{tabular}

Tv: T. vivax; Tb: T. brucei s.l.; Tcf: T. congolense forest type; Tcs: T. congolense savannah type.

Table 3. Frequency of mixed infections of trypanosomes in tsetse.

\begin{tabular}{|c|c|c|c|c|c|c|c|}
\hline Trypanosomes in tsetse & Infection profile & $\mathrm{Gt}$ & Gpp & Gpg & Gmed & Total & Frequency $(\%)$ \\
\hline 1 & $\mathrm{Tv}$ & 9 & 1 & - & - & 10 & 31.2 \\
\hline 1 & $\mathrm{~Tb}$ & 1 & - & 1 & - & 2 & 6.3 \\
\hline 1 & Tcf & - & 2 & - & - & 2 & 6.3 \\
\hline 1 & Tes & 3 & 2 & 1 & 1 & 7 & 21.9 \\
\hline 2 & $\mathrm{Tv}+\mathrm{Tcs}$ & 3 & - & - & - & 3 & 9.4 \\
\hline 2 & $\mathrm{Tcs}+\mathrm{Tb}$ & - & 1 & - & - & 1 & 3.1 \\
\hline 2 & Tef + Tes & 4 & 1 & - & 1 & 6 & 18.7 \\
\hline 3 & $\mathrm{Tcf}+\mathrm{Tcs}+\mathrm{Tb}$ & - & 1 & - & - & 1 & 3.1 \\
\hline Total & & 20 & 8 & 2 & 2 & 32 & 100 \\
\hline
\end{tabular}

Gt: G. tachinoides, Gpg: G. p. gambiensis, Gpp: G. p. palpalis, Gmed: G. medicorum, Tv: T. vivax, Tb: T. brucei s.1, Tcf: T. congolense forest type, Tcs: T. congolense savannah type.

animal hosts $[9,25]$ may explain this increased infection rate. The absence of infected salivary glands among all the dissected tsetse observed in the present study confirms that the natural infection rate of tsetse salivary glands by trypanosomes of brucei complex remains very low $[10,15]$.

The three targeted trypanosome species in our study, namely $T$. vivax, T. brucei and T. congolense, which are major parasites of human and animal trypanosomiasis in Africa were identified in this area. Specific primers were used to identify the exact type and species of trypanosomes circulating in this area. For T. vivax, specific primers for the West Africa type were used. However, we did not use specific primers for subtypes of $T$. brucei, $T$. simiae and T. congolense Kilifi, which could partly explain the high rate of $24.1 \%$ of non-identified trypanosomes, as well as the presence of other, non-pathogenic trypanosomes not tested in this study (reptilian trypanosomes for instance) [18]. From the pathogenic trypanosomes identified, trypanosomes of cattle are the most encountered along Comoé River including $T$. congolense and $T$. vivax. T. congolense accounted for $61.4 \%$ of the identified trypanosomes circulating in this area. T. congolense savannah type accounted for $41 \%$ of infections in contrast to studies in HAT foci in the forest areas of Côte d'Ivoire [12, 20, 21] and Cameroon [22], where $T$. congolense forest type was predominant. A significantly higher infection rate of $T$. congolense savannah type was obtained in the Malanga HAT focus (savannah area) in the Democratic Republic of Congo [27]. This shows that T. congolense savannah type would be best suited to animal hosts living in savannah, while $T$. congolense forest type would be suited for animals living in the forest area. However, the extensive use of PCR and DNA probes on naturally infected tsetse has shown that "savannah" trypanosomes may be found in "forest" tsetse [20-22], as well as the reverse, i.e., "forest" trypanosomes in "savannah" tsetse [17]. Also, a significant association between the savannah and forest type of $T$. congolense in tsetse of the palpalis and morsitans groups has been demonstrated by Solano et al. [28]. The presence of the two species, T. congolense and T. vivax, known for their pathogenicity to cattle is an indicator of the magnitude of AAT in this area, especially near the Comoé National Park (north) and in Groumania (centre). This suggests that livestock development along this important river will be seriously hampered by the nagana if control measures against tsetse flies and trypanosomes are not taken prior to cattle introduction. The low prevalence of T. brucei in tsetse along Comoé River here contrasts with the high prevalence found in HAT foci in Cameroon [22].

Individually, tsetse flies have been variously infected by trypanosomes. G. medicorum was infected only by subtypes of $T$. congolense, which certainly reflects its preference for wild ungulates as a feeding source. T. brucei s.l. was encountered in G. p. palpalis, G. p. gambiensis and G. tachinoides. G. p. gambiensis was infected by T. brucei and T. congolense forest type. All species of trypanosomes were found in G. p. palpalis and $G$. tachinoides, proving that they are the main vectors of human and animal trypanosomiasis in West Africa $[2,4,14]$. T. congolense savannah type was found in all species of tsetse fly, an observation also reported in Tanzania [18]. The presence of $T$. brucei along the Comoé River must draw our attention because of the proximity of Abengourou, a former HAT focus [6]. With internal population movements in 
Côte d'Ivoire due to the socio-political crisis, it cannot be excluded that sleeping sickness patients from areas at risk of HAT, for instance the central-west $[6,14]$ could move to areas where major vectors and possibly the parasite are present. Therefore, surveillance of HAT should take this into account. Mixed infections that represent a quarter of the infections are in a relatively large proportion and above all increase the risk of AAT. Indeed, T. congolense savannah type is present in all combinations of multiple infections. Mixed infections were also observed in the central-west HAT foci in Côte d'Ivoire including Sinfra and Daloa $[12,20]$.

The trypanosomiasis risk is usually related to tsetse flies density, trypanosome infection rates, and contact between host and vectors [31]. Along the Comoé River, these factors are present in varying degrees. In this area, tsetse flies found are among the major vectors of HAT and AAT in Côte d'Ivoire and the trypanosome infection rate is relatively high. This study showed that pathogenic trypanosomes and the major vectors of HAT and AAT are present along the Comoé River. It is therefore necessary to take these data into account before developing activities such as livestock rearing.

Acknowledgements. The authors are grateful to IPR's and CIRDES' technicians for their technical support. Our thanks also go to administrative and traditional authorities of locations visited as well as guides and helpers. This study was mainly supported by a grant from IRD through JEAI ECOVECTRYP.

\section{References}

1. Anonyme. Département et districts de Côte d'Ivoire. 2005. Office Ivoirien du Tourisme et de l'Hôtellerie. Le groupe intercommunication.

2. Bouyer J, Koné N, Bengaly Z. 2013. Dynamics of tsetse natural infection rates in the Mouhoun river, Burkina Faso, in relation with environmental factors. Frontiers in Cellular and Infection Microbiology, 29(3), 47.

3. Büscher P, Mertens P, Leclipteux T, Gilleman Q, Jacquet D, Mumba-Ngoyi D, Pyana PP, Boelaert M, Lejon V. 2014. Sensitivity and specificity of HAT Sero-K-SeT, a rapid diagnostic test for serodiagnosis of sleeping sickness caused by Trypanosoma brucei gambiense: a case-control study. Lancet Global Health, 2(6), e359-e363.

4. Cattand P. 2001. Lépidémiologie de la trypanosomiase humaine africaine : une histoire multifactorielle complexe. Médecine Tropicale, 61, 313-322.

5. Challier A, Laveissiere C. 1973. Un nouveau piège pour la capture des glossines (Glossina : Diptera, Muscidae) : description et essais sur le terrain. Cahiers O.R.S.T.O.M. Série Entomologie médicale et Parasitologie, 11(4), 251-262.

6. Dje NN, Miezan TW, N'guessan P, Brika P, Doua F, Boa F. 2002. Distribution géographique des trypanosomés pris en charge en Côte d'Ivoire de 1993 à 2000. Bulletin de la Société de Pathologie Exotique, 95(5), 359-361.

7. Franco JR, Simarro PP, Diarra A, Jannin JG. 2014. Epidemiology of human African trypanosomiasis. Clinical Epidemiology, 6(6), 257-275.

8. Gibson W. 2009. Species-specific probes for the identification of the African tsetse-transmitted trypanosomes. Parasitology, $136,1501-1507$.
9. Gouteux JP, Kienou JP. 1982. Observations sur les glossines d'un foyer forestier de trypanosomiase humaine en Côte d'Ivoire 5. Peuplement de quelques biotopes caractéristiques : plantations, forêts et galeries forestières, en saison des pluies. Cahiers O.R.S.T.O.M., Série Entomologie médicale et Parasitologie, 20(1), 41-61.

10. Harmsen R. 1973. The nature of the establishment barrier for Trypanosoma brucei in the gut of Glossina pallidipes. Transactions of the Royal Society of Tropical Medicine and Hygiene, 67, 364-373.

11. Hu C, Askoy S. 2006. Innate immune responses regulate trypanosome parasite infection of the tsetse fly Glossina morsitans morsitans. Molecular Microbiology, 60, 1194-1204.

12. Jamonneau V, Ravel S, Koffi M, Kaba D, Zeze DG, Ndri L, Sane B, Coulibaly B, Cuny G, Solano P. 2004. Mixed infections of trypanosomes in tsetse and pigs and their epidemiological significance in a sleeping sickness focus of Côte d'Ivoire. Parasitology, 129(6), 693-702.

13. Kaba D. 2014. Morphométrie géométrique appliquée aux tsétsé : taxonomie et identification de populations isolées pour la lutte contre les tsé-tsé et les trypanosomoses, Thèse d'université, Université Félix Houphouët Boigny, Côte d'Ivoire.

14. Kaba D, Dje NN, Courtin F, Oke E, Koffi M, Garcia A, Jamonneau V, Solano P. 2006. L'impact de la guerre sur l'évolution de la THA dans le centre-ouest de la Côte d'Ivoire. Tropical Medicine and International Health, 11(2), 136-143.

15. Kazadi JML, Van Hees J, Jochems M, Kageruka P. 1991. Etude de la capacité vectorielle de Glossina palpalis gambiensis (Bobo Dioulasso) vis-à-vis de Trypanosoma brucei brucei EATRO 1125. Revue d'Elevage et de Médecine vétérinaire des Pays tropicaux, 44(4), 431-442.

16. Laveissiere C, Challier A. 1981. La répartition des glossines en Côte d'Ivoire. Cartes à $1 / 2.000 .000^{\mathrm{e} m e}$ et notice explicative. ORSTOM, Paris.

17. Lefrançois T, Solano P, Bauer B, Kabore I, Touré SM, Cuny G, Duvallet G. 1999. Polymerase chain reaction characterization of trypanosomes in Glossina morsitans submorsitans and G. tachinoides collected on the game ranch of Nazinga, Burkina Faso. Acta Tropica, 72, 65-77.

18. Malele II, Magwisha BH, Nyingilili SH, Mamiro AK, Rukambile JE, Daffa WJ, Lyaruu AE, Kapange AL, Kasilagila KG, Lwitiko KN, Msami MH, Kimbita NE. 2011. Multiple Trypanosoma infections are common amongst Glossina species in the new farming areas of Rufiji district, Tanzania. Parasites \& Vectors, 17(4), 217.

19. Masake RA, Njuguna JT, Brown CC, Majiwa PA. 2002. The application of PCR-ELISA to the detection of Trypanosoma brucei and T. vivax infections in livestock. Veterinary Parasitology, 105, 179-189.

20. Masiga DK, McNamara JJ, Laveissière C, Truc P, Gibson WC. 1996. A high prevalence of mixed trypanosome infections in tsetse flies in Sinfra, Côte d'Ivoire, detected by DNA amplification. Parasitology, 112(1), 75-80.

21. McNamara JJ, Laveissière C, Masiga DK. 1995. Multiple trypanosome infections in wild tsetse in Côte d'Ivoire detected by PCR analysis and DNA probes. Acta Tropica, 59(2), 85-92.

22. Morlais I, Grebaut P, Bodo JM, Djoha S, Cuny G, Herder S. 1998. Detection and identification of trypanosomes by polymerase chain reaction in wild tsetse flies in Cameroon. Acta Tropica, 70(1), 109-117.

23. Palmer JJ, Surur EI, Checchi F, Ahmad F, Ackom FK, Whitty CJ. 2014. A mixed methods study of a health worker training 
intervention to increase syndromic referral for gambiense human African trypanosomiasis in South Sudan. PLoS Neglected Tropical Diseases, 8(3), e2742.

24. Picozzi K, Tilley A, Fevre EM, Coleman PG, Magona JW, Oditt M, Eisler MC, Welburn SC. 2002. The diagnosis of trypanosome infections: applications of novel technology for reducing disease risk. African Journal of Biotechnology, 1, 39-45.

25. Sané B, Laveissière C, Méda AH. 2000. Diversité du régime alimentaire de Glossina palpalis palpalis en zone forestière de Côte d'Ivoire : relation avec la prévalence de la trypanosomiase humaine africaine. Tropical Medicine and International Health, 5(1), 73-78.

26. Simarro PP, Jannin J, Cattand P. 2008. Eliminating human African Trypanosomiasis: where do we stand and what comes next? PLoS Medicine, 5(2), e55.

27. Simo G, Silatsa B, Flobert N, Lutumba $P$, Mansinsa $P$, Madinga J, Manzambi E, De Deken R, Asonganyi T. 2012.
Identification of different trypanosome species in the mid-guts of tsetse flies of the Malanga (Kimpese) sleeping sickness focus of the Democratic Republic of Congo. Parasites \& Vectors, 19(5), 201.

28. Solano P, Guégan JF, Reifenberg JM, Thomas F. 2001. Trying to predict and explain the presence of African trypanosomes in tsetse flies. Journal of Parasitology, 87(5), 1058-1063.

29. Swallow B. 2000. Impacts of Trypanosomiasis on African Agriculture. PAAT Technical and Scientific (Series 2). FAO: Rome.

30. Wastling SL, Welburn SC. 2011. Diagnosis of human sleeping sickness: sense and sensitivity. Trends in Parasitology, 27, 394-402.

31. WHO 2013. Control and Surveillance of African Trypanosomiasis, WHO Technical Report Series, No. 984, World Health Organization: Geneva.

Cite this article as: Djohan V, Kaba D, Rayaissé J-B, Dayo G-K, Coulibaly B, Salou E, Dofini F, Kouadio ADMK, Menan H \& Solano P: Detection and identification of pathogenic trypanosome species in tsetse flies along the Comoé River in Côte d'Ivoire. Parasite, 2015, 22, 18.

\section{O PARASTE}

An international open-access, peer-reviewed, online journal publishing high quality papers on all aspects of human and animal parasitology

Reviews, articles and short notes may be submitted. Fields include, but are not limited to: general, medical and veterinary parasitology; morphology, including ultrastructure; parasite systematics, including entomology, acarology, helminthology and protistology, and molecular analyses; molecular biology and biochemistry; immunology of parasitic diseases; host-parasite relationships; ecology and life history of parasites; epidemiology; therapeutics; new diagnostic tools.

All papers in Parasite are published in English. Manuscripts should have a broad interest and must not have been published or submitted elsewhere. No limit is imposed on the length of manuscripts.

Parasite (open-access) continues Parasite (print and online editions, 1994-2012) and Annales de Parasitologie Humaine et Comparée (1923-1993) and is the official journal of the Société Française de Parasitologie. 